Journal Universitas Muhammadiyah Gresik Engineering, Social Science, and Health International Conference (UMGESHIC)

UMGCINMATIC : $1^{\text {st }}$ Rethinking Education during Covid-19 Era: Challange and Innovation

\title{
USE OF RUNNING LED MEDIA TO REDUCE MISCONCEPTIONS IN ORDER TO IMPROVE THE RESULTS OF SCIENCE LEARNING IN SD
}

\author{
Author \\ Harmadi Sampurna Putra, Nataria Wahyuning Subayani, Irwani Zawawi \\ University of Muhammadiyah Gresik Harmadi0704@ gmail.com
}

\begin{abstract}
This study aims to (1) reduce the misconception of students on science subjects of human circulation, (2) improve science learning outcomes, (3) to know the feasibility of running running media on science learning. Viewing the results obtained by the study researchers through observation activities obtained data on the results of learning 10 out of 34 students under the KKM. The number of learners who did not score above the KKM, indicated a misconception. misconceptions arise due to abstract material in the eyes of the IPA lesson presented without the media. Therefore, researchers apply the use of media in this study. The type of research used in this research is Classroom Action Research (PTK) Kemmis\& Taggart model consisting of four components namely planning, action, observation and reflection. This research was conducted at SDN CagakAgung District of Cerme, Gresik Regency. The subject of this research is all students of class V which amounted to 34 children. Data collection techniques used in this study are tests and certainty of response index (CRI). The test instrument consists of fifteen description questions and five true-false questions. In addition, to determine the level of misconception done with pretest-postest implementation. Data analysis techniques used in this study are analysis of student learning outcomes, misconception analysis and analysis of implementation implementation of learning plan (RPP). The results obtained from this study is the misconception rate may decrease by $50 \%$ from the initial data misconception taken through pretest that is equal to $74 \%$. The posttest result shows a misconception result of $24 \%$. Student learning outcomes indicate a significant increase. From the evaluation result one obtained the average score of participants is 74 and on the evaluation of two average value that is 87 . In the evaluation test of the lowest value is 60 and the highest value is 96 . In the evaluation test the two lowest values are 68 and the highest value is 100 . So that obtained the increase of learning outcomes of learners by $47 \%$ of the evaluation test one. The result of one class evaluation by $41 \%$ learners get value above KKM. In the second evaluation, classically $88 \%$ of learners get the above KKM values.
\end{abstract}

Keywords: Misconception, Learning Media, Running Led 


\section{UMGCINMATIC : $1^{\text {st }}$ Rethinking Education during Covid-19 Era: Challange and Innovation}

Volume 1 No 2

\section{INTRODUCTION}

The demands in the world of education today, educators and education staff as well as all students are required to keep up with the times that are so fast. So that education in Indonesia can keep up with the increasingly sophisticated times, teachers must implement education that uses innovative learning media. The use of learning media is also very helpful for students in understanding the learning material. In accordance with the opinion (Zaman, Pd, \& Eliyawati, 2010) that learning media has a very important position in improving student learning outcomes. The use of interesting media in learning is expected to help students understand the material presented by the teacher in class.

Implementation of learning without using media, causes misconceptions or errors in understanding the concept, maybe even students do not understand the concept, so that students find it difficult to remember the learning material. The use of learning media can increase motivation and interest in learning which can affect students' understanding so that learning outcomes can also increase. This statement is in accordance with the opinion (Hamdu \& Agustina, 2011) that "motivation and interest of students greatly affect student learning outcomes". Through learning media, the teacher's explanation regarding the material becomes easier for students to understand because it minimizes the diversity of students' imaginations on the material presented by the teacher.

Seeing the reality and problems that arise in the world of education today, it is hoped that there will be the best solution to solve these problems. One solution that can solve these problems is to use innovative learning media to minimize student misconceptions. Learning media running led (flickering lights) is one of the media that can be used to convey science material about human blood circulation. The use of Running Led media equipped with red and blue LED lights can represent human blood circulation that is close to real. So that the use of Running Led media in delivering science material which tends to be abstract, can be presented with conditions that are close to real. Submission of abstract material using media makes it easier for students to understand the concept.

Based on observations, researchers got data on students' daily assignments that 18 out of 34 students scored below the KKM. In addition, information from teachers obtained through interviews, the results of science learning for grade 5 students on the material of human blood circulation as many as 24 children can achieve scores above the KKM and 10 children below the KKM, the KKM value determined by the school is 75 . This condition is very concerning. if only left alone without thinking about what the problem is and what the solution is. Students who have a low KKM are due to the learning process without media, without cross-checking so that in the material for the process of human blood circulation, students have a variety of imaginations and can cause misconceptions. Learning outcomes that are low or below the KKM indicate that misconceptions occur in class V SDN Cagak Agung. Teachers who do not use media cause students' interest to decrease because students are required to understand the material without a bridge of understanding (media) that is close to real. Therefore, it is necessary to have a solution that can solve this problem. From the problems above, the researcher raised the title "Use of Running Led media to reduce misconceptions in order to improve science learning outcomes in elementary schools" with the aim of providing solutions to these problems. The reason the researcher took the title is that the use of Running Led media can represent human blood circulation close to real. 


\section{RESEARCH METHODS}

This type of research uses descriptive quantitative classroom action research which discusses misconceptions about science, especially in class $\mathrm{V}$ material on human blood circulation and is related to improving student learning outcomes. The subjects of this study were the fifth grade students of SDN Cagak Agung, Cerme District, for the 2017-2018 school year. The number of students as many as 34 people, with details, 9 women and 25 men. The research procedure is the steps that have been arranged step by step for the implementation of the research. In general, there are many steps that researchers must take which are divided into three stages, namely the initial stage, the implementation stage, and the final stage.

The data collection technique in this study was a test and a Certainty of Response Index (CRI) table. The test is used to measure the learning outcomes of participants and the abilities or knowledge possessed by students. CRI is a measure of the level of confidence in the response or understanding of the concepts possessed by students in answering questions. From the CRI table, it can be seen the level of misconception experienced by students. The research instruments used in this study were test sheets (Exams) and CRI sheets. The test sheet is in the form of ten numbered questions in the form of five arkan Hessay questions and five true-false questions. The CRI sheet is a misconception analysis based on the results of the pretest and posttest. Students are given ten numbers of pretest questions and ten numbers of true-false posttest questions. The results of the pretestl-posttest are presented in proportion to determine the level of misconceptions experienced by students.

\section{RESULTS AND DISCUSSION}

The data in this study were obtained by means of a test and a Certainty of Response Index (CRI). The test was conducted to determine the learning outcomes of students, CRI was conducted to determine the level of students' misconceptions that were applied to the implementation of the pretest and posttest.

Table 1. Percentage of Individual Misconceptions

\begin{tabular}{|l|c|c|c|c|c|}
\hline \multirow{2}{*}{ No. } & \multirow{2}{*}{ Name } & \multicolumn{2}{|c|}{ Pretest } & \multicolumn{2}{|c|}{ Posttest } \\
\cline { 2 - 6 } & & Total & $\mathbf{\%}$ & Total & \% \\
\hline 1. & ARP & 6 & 60 & 1 & 10 \\
\hline 2. & AF & 0 & 0 & 0 & 0 \\
\hline 3. & ABP & 4 & 40 & 0 & 0 \\
\hline 4. & AB & 4 & 40 & 1 & 10 \\
\hline 5. & DPP & 0 & 0 & 0 & 0 \\
\hline 6. & ETD & 4 & 40 & 0 & 0 \\
\hline 7. & EIP & 0 & 0 & 0 & 0 \\
\hline 8. & FHP & 0 & 0 & 0 & 0 \\
\hline 9. & MR & 3 & 30 & 0 & 0 \\
\hline 10. & MH & 4 & 40 & 1 & 10 \\
\hline 11. & HL & 0 & 0 & 0 & 0 \\
\hline 12. & MSL & 3 & 30 & 0 & 0 \\
\hline
\end{tabular}


UMGCINMATIC : $1^{\text {st }}$ Rethinking Education during Covid-19 Era: Challange and Innovation Volume 1 No 2

\begin{tabular}{|l|c|c|c|c|c|}
\hline 13. & FNF & 3 & 30 & 0 & 0 \\
\hline 14. & MAF & 2 & 20 & 0 & 0 \\
\hline 15. & MISF & 3 & 30 & 0 & 0 \\
\hline 16. & MYW & 0 & 0 & 0 & 0 \\
\hline 17. & MR & 4 & 40 & 0 & 0 \\
\hline 18. & MNR & 2 & 20 & 1 & 10 \\
\hline 19. & SA & 0 & 0 & 0 & 0 \\
\hline 20. & M & 3 & 30 & 1 & 10 \\
\hline 21. & MAM & 4 & 40 & 0 & 0 \\
\hline 22. & ND & 0 & 0 & 0 & 0 \\
\hline 23. & RMS & 4 & 40 & 0 & 0 \\
\hline 24. & S & 2 & 20 & 0 & 0 \\
\hline 25. & WY & 4 & 40 & 0 & 0 \\
\hline 26. & WZ & 4 & 40 & 0 & 0 \\
\hline 27. & YKD & 3 & 30 & 0 & 0 \\
\hline 28. & AFT & 4 & 40 & 1 & 10 \\
\hline 29. & YIB & 4 & 40 & 3 & 30 \\
\hline 30. & ZU & 5 & 50 & 1 & 10 \\
\hline 31. & HPP & 3 & 30 & 0 & 0 \\
\hline 32. & DAS & 4 & 40 & 0 & 0 \\
\hline 33. & NH & 4 & 40 & 0 & 0 \\
\hline 34. & FH & 0 & 0 & 0 & 0 \\
\hline
\end{tabular}

\section{Misconception Level Diagram}

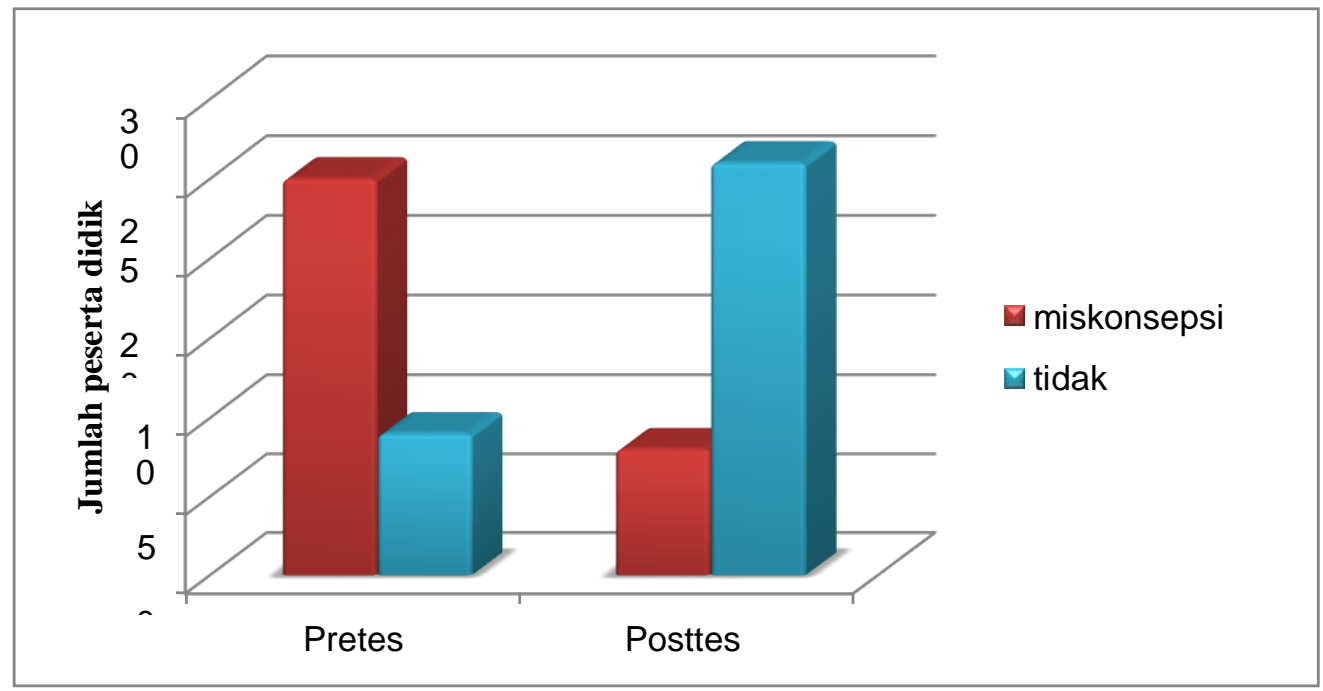

Figure 1. Improved Learning Outcomes (Evaluation)

Student learning outcomes have increased quite well. In the first cycle, as many as twenty students could not achieve a score above the KKM. A total of fourteen students scored above the 
KKM. In cycle II, as many as thirty students can achieve scores above the KKM. A total of four students scored below the KKM. From these data, it can be seen that there is a significant increase in student learning outcomes.

Table 2. Percentage of learning outcomes

\begin{tabular}{|c|c|c|c|c|c|}
\hline \multirow[b]{2}{*}{ No. } & \multirow[b]{2}{*}{ Name } & \multicolumn{2}{|c|}{ Individual } & \multicolumn{2}{|c|}{ Klasikal } \\
\hline & & Evaluasi 1 & Evaluasi 2 & Evaluasi 1 & $\begin{array}{c}\text { Evaluasi } \\
2\end{array}$ \\
\hline 1. & ARP & $60 \%$ & $68 \%$ & \multirow{34}{*}{$41 \%$} & \multirow{34}{*}{$88 \%$} \\
\hline 2. & $\mathrm{AF}$ & $76 \%$ & $88 \%$ & & \\
\hline 3. & $\mathrm{ABP}$ & $80 \%$ & $92 \%$ & & \\
\hline 4. & $\mathrm{AB}$ & $88 \%$ & $96 \%$ & & \\
\hline 5. & DPP & $72 \%$ & $96 \%$ & & \\
\hline 6. & ETD & $76 \%$ & $96 \%$ & & \\
\hline 7. & EIP & $80 \%$ & $100 \%$ & & \\
\hline 8. & FHP & $84 \%$ & $100 \%$ & & \\
\hline 9. & MR & $72 \%$ & $92 \%$ & & \\
\hline 10. & $\mathrm{MH}$ & $80 \%$ & $96 \%$ & & \\
\hline 11. & HL & $88 \%$ & $96 \%$ & & \\
\hline 12. & MSL & $60 \%$ & $76 \%$ & & \\
\hline 13. & FNF & $68 \%$ & $76 \%$ & & \\
\hline 14. & MAF & $72 \%$ & $88 \%$ & & \\
\hline 15. & MISF & $72 \%$ & $80 \%$ & & \\
\hline 16. & MYW & $80 \%$ & $92 \%$ & & \\
\hline 17. & MR & $64 \%$ & $72 \%$ & & \\
\hline 18. & MNR & $72 \%$ & $76 \%$ & & \\
\hline 19. & SA & $96 \%$ & $100 \%$ & & \\
\hline 20. & $\mathrm{M}$ & $60 \%$ & $76 \%$ & & \\
\hline 21. & MAM & $88 \%$ & $96 \%$ & & \\
\hline 22. & ND & $72 \%$ & $96 \%$ & & \\
\hline 23. & RMS & $72 \%$ & $88 \%$ & & \\
\hline 24. & $S$ & $60 \%$ & $68 \%$ & & \\
\hline 25. & WY & $60 \%$ & $80 \%$ & & \\
\hline 26. & WZ & $72 \%$ & $88 \%$ & & \\
\hline 27. & YKD & $76 \%$ & $96 \%$ & & \\
\hline 28. & AFT & $68 \%$ & $72 \%$ & & \\
\hline 29. & YIB & $72 \%$ & $80 \%$ & & \\
\hline 30. & $\mathrm{ZU}$ & $68 \%$ & $80 \%$ & & \\
\hline 31. & HPP & $72 \%$ & $92 \%$ & & \\
\hline 32. & DAS & $68 \%$ & $76 \%$ & & \\
\hline 33. & $\mathrm{NH}$ & $80 \%$ & $88 \%$ & & \\
\hline 34. & $\mathrm{FH}$ & $88 \%$ & $100 \%$ & & \\
\hline
\end{tabular}




\section{UMGCINMATIC : $1^{\text {st }}$ Rethinking Education during Covid-19 Era: Challange and Innovation} Volume 1 No 2

With the provisions of the Minimum Completeness Criteria (KKM) from the school $=75 \%$
Individual completion $=$
$100 \%=$

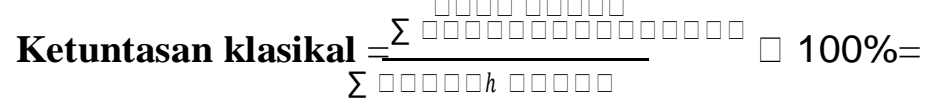

\section{Discussion}

Based on research that has been done at SDN Cagak Agung Cerme District, using Running Led media for two meetings. Misconception data was obtained which was then analyzed by the researcher. The misconception data was obtained through a pretest-posttest test with twenty true-false questions. Researchers conducted an analysis of the results of the pretest, obtained data on students who experienced misconceptions by $74 \%$ and those who did not experience misconceptions by $26 \%$. In the posttest results, data obtained from students who experience misconceptions by $24 \%$ and students who do not experience misconceptions by $76 \%$. From these data, it can be seen that there is a decrease in the level of misconceptions experienced by students. The decrease in the number of misconceptions by $50 \%$ from the initial data of $74 \%$ to $24 \%$.

Learning outcomes data were obtained through an evaluation test in the form of ten questions in the first cycle evaluation and ten numbers in the second evaluation test. In the analysis of the results of the student evaluation tests, data or scores were obtained when evaluating the first cycle individually, the highest score was 96 and the lowest score was 60. During the second cycle evaluation, the data or individual scores were obtained, the highest score was 100 and the lowest score was 68 . classical data obtained from the evaluation of the first cycle, students whose scores are above the KKM are $41 \%$ and in the second cycle evaluation are $88 \%$. From these data, the increase in learning outcomes is seen by $47 \%$ of the initial data.

Based on these data, it can be concluded that by using the Runnning Led media the level of misconception can decrease so that student learning outcomes increase. This can be seen in the graph of the level of misconceptions during the Pretest-Posttest and the percentage of complete learning both individually and classically. Learning media provides opportunities for students to be active and creative. In learning by using media, each student can explore his curiosity more so that it can increase the enthusiasm for learning and achieve learning goals.

\section{CONCLUSION}

Based on the results of research and discussion in this study, the evidence obtained from the results of data analysis is as follows.

1. The results of misconceptions in the science subject of the human circulatory system material delivered using the Running Led learning media can decrease. The initial data on misconceptions obtained from 34 students through the Pretest showed that $74 \%$ of the students had misconceptions and in the Posttest data, it was obtained that $24 \%$ of the students had misconceptions.

2. The learning outcomes of students in science subjects on the human circulatory system material delivered using Running Led media can increase. Judging from the evaluation data one, it was obtained that $41 \%$ of students could not exceed the KKM with the lowest score of 60 and the highest score of 96 . Compared to the evaluation data of two, it was found that $88 \%$ of the students could exceed the KKM with the lowest score of 68 and the highest score of 100. 
3. The results of using the Running Led learning media in classroom action research (CAR) which was carried out in class V of SDN Cagak Agung, Cerme sub-district, regarding human blood circulation, could reduce the level of misconceptions by $50 \%$ from the initial misconception data obtained by researchers. Improved learning outcomes can be obtained because the delivery of learning materials is delivered using media that are close to real. The use of appropriate learning models and media also plays a role in reducing misconceptions so that learning outcomes can increase.

\section{REFERENCES}

Hamdu, G., \& Agustina, L. (2011). Pengaruh Motivasi Belajar Peserta didik Terhadap Pestasi Belajar Ipa Di Sekolah Dasar. Jurnal Penelititan Pendidikan, 12(1), 90-96.

Hasan, S., D. Bagayoko, D., And Kelley , E. L., (1999). misconceptions And The Certainty Of Response Index(Cri). Journal Physics Educations, 34 (5) ,Pp, 294-299, September1999

Slamet, A., Nataria, W. S., Ismal, M., (2015). Science Misconceptions Profile of an Elementary Teacher Candidate Collegian

Zaman, B., Pd, M., \& Eliyawati, H. C. (2010). Media Pembelajaran Anak Usia Dini. Media Pembelajaran Anak Usia Dini, 34. Retrieved From Http://File.Upi.Edu/Direktori/Fip/Jur._Pgtk/197010221998022-

Cucu_Eliyawati/Media_Pembelajaran_Anak_Usia_Dini-Ppg_Upi.Pdf 